\title{
De schilder Hans Memling. Als Brugs poorter financieel, sociaal en politiek doorgelicht.
}

\author{
Albert Janssens
}

Op 11 augustus 1494 overleed de schilder Hans Memling. ${ }^{1}$ Om de 500 ste verjaardag van zijn sterfdatum te herdenken werd er dan ook in Brugge in de zomer van 1994 een grootse tentoonstelling met werken van de schilder opgezet. In het zog van die herdenking zagen ook enkele publicaties het daglicht waarvan sommige ronduit indrukwekkend mogen genoemd worden. ${ }^{2}$ Door die vlaag van heroplevende belangstelling voor het oeuvre van Memling wordt het gebrek aan gegevens over de man zelf nog schrijnender aangevoeld. Het lijkt niet realistisch te veronderstellen dat er nog veel bronnen met spectaculaire gegevens over zijn leven zullen ontdekt worden. $\mathrm{Bij}$ het nalezen van het summiere biografische materiaal dat over Memling bestaat, maakten we bij onszelf de bedenking dat de weinige gegevens die ter beschikking staan eerder geïsoleerd worden gehouden en niet of nauwelijks worden geconfronteerd met wat zich in die periode in Brugge afspeelde. Als we nu eens Memling zouden bekijken, niet specifiek als schilder, maar als een doorsnee Brugse poorter die in een bijzonder woelige tijd leefde, zou dit dan niet enige verheldering kunnen werpen op reeds gekende feiten?

De biografische basisgegevens over Hans Memling zijn zo beperkt dat ze hier in enkele regels kunnen samengevat worden.

Wat is gekend? Zijn geboorteplaats in Duitsland nl. Seligenstadt maar niet zijn geboortedatum. Hij wordt als Brugs poorter ingeschreven in 1465. Hij huwt vrouw Tanne maar behalve het moment waarop ze overlijdt, weet men verder niets over haar. Het koppel had drie kinderen waarvan de namen genoteerd staan in de staat van goed die opge-

1 Fragments inédits de Romboudt de Doppere découvert dans un manuscrit de Jacques de Meyere. Chronique brugeoise de 1491 à 1498. Uitgegeven door Dussart H., Brugge 1892. p.49. Zie ook de notitie in het register van de broederschap van Onze-Lieve-Vrouw-ter-Sneeuw aangehaald in De Vos D.: Hans Memling. Het volledige oeuvre. Antwerpen 1994, p.413.

2 Het meest volledige overzicht met een status quaestionis over de persoon van Memling is van de hand van De Vos D.: Hans Memling. Het volledige oeuvre. Antwerpen 1994. Om het notenapparaat niet extra zwaar te maken zullen we elke verwijzing naar vroeger gepubliceerd bronnenmateriaal weglaten en in het vervolg verwijzen naar de zeer volledige status quaestionis van De Vos D. tenzij de bron zelf door vroegere publicisten volgens ons niet correct werd weergegeven. 
maakt is na het overlijden van Tanne. Dit is dan ook het enige wat over de kinderen gekend is. Memling zelf overlijdt in 1494 als bezitter van twee naast elkaar gelegen huizen in de Sint-Jorisstraat te Brugge. ${ }^{3}$

Vanuit de studie van het sociaal-economisch bronnenmateriaal in Brugge over het tijdvak 1477-1492, werd onze aandacht gevestigd op een vorm van informatie die we met betrekking tot Memling eigenlijk nog niet zijn tegengekomen. Als er al geen spectaculaire bronvondsten meer verwacht moeten worden over het leven van Memling dan viel het ons op dat in een aantal bronnen de naam van de schilder niet wordt aangetroffen, terwijl volgens het algemene aanvoelen, dit wel het geval had moeten zijn. Dit soort 'ontbreken van informatie' kan even duidelijk bepaalde aspecten belichten als welke andere soort bron ook.'

\section{Hans Memling: financieel.}

In een eerste onderdeel zullen we de financiële draagkracht van Memling nader onderzoeken. De weinige feiten die daarover bekend zijn zullen we in perspectief plaatsen tegen de achtergrond van algemene gebeurtenissen die de Brugse poorters collectief hebben meegemaakt en die dus ook Hans Memling beleefd heeft. Zoals verder zal blijken kan het 'ontbreken' van gegevens hierbij zeker nuttige informatie bijbrengen.

Er bestaat een soort stilzwijgende consensus dat Hans Memling, een begenadigd schilder, met een ruime productie aan schilderijen en een aantal gerenomeerde klanten, wel financieel en materieel in goede doen zal geweest zijn.

De indruk dat Memling tot de financiële elite van de stad zou behoord hebben, steunt eigenlijk op één enkele vermelding in de Brugse stadsrekening van 1480/81 waarin staat dat Memling $20 \mathrm{~s}$ gr geleend heeft aan de stad Brugge. ${ }^{5}$ De vraag is natuurlijk altijd in welke context een dergelijke betaling geplaatst moet worden? Wanneer men de periode

3 De Vos D.:Memling., p.407 e.v.

4 De enige "nieuwe" bron die wij aan de bestaande kunnen toevoegen is de voogdenlijst opgemaakt na het overlijden van vrouw Tanne en waaruit blijkt dat zij minstens een jaar vroeger gestorven is dan de datum waarop de wezengoederen werden geregistreerd terwijl ook de beroepsactiviteit van beide voogden wordt gegeven. De tekst staat afgedrukt bij noot 57. Maar laten we ecrlijk zijn: een spectaculaire vondst kan men dit zeker niet noemen.

5 Stadsarchief Brugge (SAB), stadsrekening 1480-81 f 52r. 
1477-1492 bestudeert, dan springen de vele financiële lasten die de Brugse bevolking worden opgelegd nadrukkelijk uit het totaalbeeld naar boven. Vooral Maximiliaan van Oostenrijk vertoont een onlesbare gelddorst. De Bruggelingen worden dan ook, om diverse redenen, overstelpt met allerlei vormen van taksen zoals maandgeld, hoofdgeld, cafcoengeld enzovoort. Specificaties over dit soort heffingen worden in de bronnen niet gegeven maar over het feit van de heffingen zelf worden we occasioneel wel ingelicht. ${ }^{6}$ De nominale lijst waarop Memling voorkomt in de stadsrekening $1480 / 81$ is een vorm van verkapte belasting van een gans andere soort. In de aangehaalde periode komt de stad Brugge regelmatig in financiële ademnood en neemt dan zijn toevlucht tot wat zij zelf noemen: een "lening".

Over een periode van 13 jaar werden meerdere dergelijke "leningen" opgelegd meer bepaald in de jaren 1477, 1478, 1480, 1482, 1487, 1488, okt. 1490 en dec. 1490. Vanaf het conflict 1488-1490 zijn de stadsfinancies door de oorlogsschulden die de stad moet betalen, vooral na de Vrede van Tours en de Vrede van Damme, er zo beroerd aan toe, dat "geleend" wordt waar maar geld te krijgen is.

De tijdgenoten zelf spreken van "lening", omdat in tegenstelling met andere taxaties deze heffingen beschouwd worden als supplementair en er beslist werd het bedrag aan de betrokkenen terug te betalen. Eigenlijk is het helemaal geen lening. Een lening veronderstelt immers dat het geleende bedrag terugbetaald wordt met rente. Van rente is er geen sprake en een termijn waarbinnen de terugbetaling moet gebeuren is meestal evenmin vastgelegd. De terugbetaling gebeurt via uitloting en laat soms jaren op zich wachten. ${ }^{9}$ In 1488

6 SAB, stadsrekening 1/3-31/8/1488 f 148r-149r. "Noch es de voors stede ghelast jeghens den persoonen hier naer verclaerst ter causen vander leenijnghe ghedaen bij manicren van maendghelde te wetene binden maenden van meyc, wedemaent, hoymaent ende ougst int jaer LXXX." Zie bv, ook SAB, stadsrekening sept.-dec. $1490 \mathrm{f} 61 \mathrm{v}$.

7 Deze lijsten zijn terug te vinden in de respectieve Brugse stadsrekeningen waar ze geboekt worden hetzij bij de ontvangsten hetzij bij de uitgaven nl. onder de vorm van terugbetalingen. Wij bereiden de publicatie voor van een verder doorgedreven studie over die gedwongen leningen. Zie ook Blockmans W: Nieuwe gegevens over de gegoede burgerij in de $13 \mathrm{e}$ en vooral 15e ceuw, Studiën betreffende de sociale strukturen le Brugge, Kortrijk en Gent in de 14e en 15e eeuw, in: Standen en Landen, 54, 1971.

8 SAB, nr 165 Civiele sententiën 1489-90 f 44r e.v. Wanneer de lakenkoopman Zegher Noppe overleden is, ontstaat een geschil tussen de erfgenamen i.v.m. de erfenis. De stad beslist de zaak nader te onderzoeken maar zal in de tussentijd een geldbeugel warin diverse muntstukken zaten ter waarde van $685 £ 9 \mathrm{~s} 10 \mathrm{~d}$ gr. en behorend tot. de erfenis als "lening" gebruiken en in termijnen van zes maanden terugbetalen.

9 SAB, stadsrekening jan.- aug. $1491 \mathrm{f} 42 \mathrm{v}$. "Ander huutgheven van achterstellen van leenijnghen vanden jaere 87 ghedaen diverssche personen byder lotinghe..." 
worden nog altijd burgers terugbetaald die in 1480 samen met Memling geld hebben geleend. ${ }^{10}$ Eigenlijk komt het hierop neer dat de stad een aantal inwoners dwingt renteloos geld voor te schieten. Wij zullen, om verwarring te vermijden en bovenal ook, omdat de bronnen die terminologie gebruiken, verder eveneens van "lening" blijven spreken maar de specifieke betekenis in de huidige context indachtig zijn.

De beslissing om een gedwongen lening op te leggen wordt meestal genomen door het schepencollege na samenspraak met de hoofdmannen van de poorterij en de dekens van de ambachten en bijna altijd met instemming van de hele bevolking. ${ }^{11}$ In een tijd waar rijkdom en eigendom niet statistisch gekend zijn door een overheidsadministratie, belast men op basis van elementen van uiterlijke weelde. ${ }^{12}$ De lening is uiteraard verplicht. Wie zich eraan onttrekt wordt door de justitie ter verantwoording geroepen. ${ }^{13}$

Halfweg de vorige eeuw schreef W.H.Weale dat Hans Memling samen met nog 106 andere burgers in mei, juni en juli $14801 £$ gr.aan de stad had gegeven om de kosten van de oorlog met Frankrijk te helpen dragen. In totaal zouden 227 burgers geld geleend hebben nl. 107 een bedrag van $1 £$ gr. en 120 een hoger bedrag. ${ }^{14}$ Deze bewering van Weale werd door latere auteurs overgenomen. De nota's van Weale waren op dat punt echter behoorlijk in de war. In werkelijkheid vermeldt de stadsrekening eerst enkel de naamlijst van diegenen die in de maand mei geleend hebben. Er zijn niet 227 maar wel 247 namen opgetekend waaronder inderdaad Memling met $1 £$ gr. $^{15}$

$10 \mathrm{SAB}$, stadsrekening maart-aug.1488 f $148 \mathrm{r}$ e.v.

11 Janssens A.: Macht en onmacht van de Brugse schepenbank in de periode 1477-1490, in: Handelingen Genootschap voor Geschiedenis te Brugge (HGG), 133,(1996). p.25 e.v.

12 De uiterlijke weelde als norm voor de selectie van de burgers wordt zeer mooi geilllustreerd door het geval van koopman Joos Florent. SAB, nr 157 Civiele Sententiën van deVierschaar, register 1490-92 f 14 r. "Joos Florent ....... comparerende dede vertooghen dat dies hij in ghebreke van leeninghe ende penninghen niet en conste fineren. Ende dat al mocht zo wesen dat hij redelicken constoffeert es van coopmanscepen ende van catheylen nochtans zo conste hij die niet vercoopen danne te grooten verliese."

$13 \mathrm{SAB}$, stadsrekening $1 / 1-31 / 8 / 1491 \mathrm{f} 151 \mathrm{r}$. " Item betaelt..Beernaert van Scoonbeke de garsoen ende andere garssoenen van deser stede over huerlieder moeyte van dat zij vele diversche persoonen ende ten diverschen stonden ghedachvaert hebben voorde voorseyde wet angaende der leenijnghen ghedaen bij zekere persoonen deser stede.." Zie ook SAB, nr 120 Hallegeboden 1490/91 f 45v.

14 W.H.Weale: Documents authentiques concernant la vie, la famille et la position sociale de Jean Memlinc, découverts à Bruges, in: Journal des Beaux-Arts 3 (1861) p. 35-36.

15 SAB, stadsrekening $1480-81$ f $49 v$ e.v. Memling staat op f $52 \mathrm{r}$. 
Alles wijst op een vluchtige notitie van de boekhouder. Achteraan in dezelfde rekening heeft hij dan de volledige lijst van de lening, geordend per zestendeel, en geïnd in de maanden mei, juni, juli en augustus 1480 geboekt. ${ }^{16}$ In totaal hebben er 875 personen geld geleend in 1480. Memling, samen met 301 andere burgers, heeft $1 £$ gr. betaald, terwijl 573 andere burgers een hoger bedrag hebben gegeven. Het hoogste bedrag dat geleend werd, weliswaar slechts door 2 personen, bedroeg niet minder dan $20 £ \mathrm{gr}$.

Het bevolkingsaantal van Brugge in die tijd wordt geraamd op ongeveer 9000 gezinshoofden. ${ }^{17}$ Als Memling één van 227 zou geweest zijn dan zou dat betekenen dat hij ruwweg tot de $2,5 \%$ rijksten van de stad zou behoord hebben en zou hij inderdaad behoorlijk welstellend zijn geweest. ${ }^{18}$ Maar hij zit in de laagste categorie van 875 welstellende burgers wat toch wel duidelijk iets anders is. Alhoewel hij volgens die gegevens nog altijd deel uitmaakt van de $10 \%$ rijkste burgers van de stad. Het bedrag zelf van $1 £$ gr. komt ongeveer overeen met het maandloon van een meester-ambachtsman uit het bouwvak. ${ }^{19}$

De geforceerde leningen van 1477, 1478 en 1482 richten zich tot een beperkte declgroep burgers maar in 1487, 1488 , okt. 1490 en dec. 1490 is een grotere groep inwoners gedwongen aan de stad te lenen zodat, althans wat de aangesproken bevolkingslaag betreft, een vergelijking met 1480 mogelijk is. ${ }^{20}$

Wanneer Memling dus in 1480 verplicht wordt te betalen komt dit omdat zijn tijdgenoten door uiterlijke tekenen van bezit vinden dat

16 SAB, stadsrekening 1480-81 f 188v e.v. Memling staat op f 203v.

17 Janssens A.: Het Brugse bevolkingsaantal in 1477, in: Van Middeleeuwen tot heden. Bladeren door Brugse kunst en geschiedenis. Brugge, 1983. p. 32.

18 "Rijk" moet hier relatief geinterpreteerd worden. Memling maakt in 1480 deel uit van de financiële bovenlaag van diegenen die belastingplichtig zijn aan de stad Brugge. Maar lang niet iedereen is belastingplichtig. Heelwat personen die tot de absolute financiële top van de stad behoren, vallen buiten de belastinglijsten omdat ze bv. als edelman of vreemdeling geprivilegieerd zijn.

19 Zie in dit verband Scholliers E.: Lonen te Brugge en in het Brugse Vrije (XVeXVIIle eeuw) p. 94-95, in: Verlinden e.a.: Dokumenten voor de Geschiedenis van Prijzen en Lonen in Vlaanderen en Brabant, dl. II A, Brugge, 1965. Zic ook Sosson J.P.: Les travaux publics de la ville de Bruges XIVe-XVe siècles. Les matériaux. Les hommes. Crédit communal de Belgique. Collection Histoire pro civilale, série in - $8^{\circ}, 11 \mathrm{r} 48$, 1977. En ook Janssens A.: Macht en onmacht, p. 6 (voetnoot 6).

20 In 1487 hebben 953 Bruggelingen betaald, in 1488: 494, in okt. 1490: 718 en in dec. 1490: 626. De leningen van 1488 en okt. 1490 en dec. 1490 werden bestudeerd door Blockmans W.: Nieuwe gegevens., p.142 e.v. 
hij een welvarend man is. ${ }^{21}$ Maar vanuit diezelfde redenering komt men dus tot de conclusie dat de tijdgenoten in 1487, 1488 , okt. 1490 en dec. 1490 niet langer menen dat Memling welstellend genoeg is om aan de geforceerde leningen die dan opgelegd worden een bijdrage te leveren, want in die vier leningen is geen spoor van Memling terug te vinden. De conclusie ligt voor de hand. In 1480 wordt hij door zijn tijdgenoten tot de $10 \%$ rijkste burgers van de stad gerekend en vanaf 1487 is dit niet meer het geval. De staat van goed wanneer Memling overlijdt, getuigt trouwens dat tussen 1487 tot zijn dood in 1494 het bezit van Memling is afgenomen. ${ }^{22}$

Zijn er gebeurtenissen van algemene aard die een verklaring kunnen geven voor de financiële achteruitgang tussen 1480 en 1487 ?

De zomer in het jaar 1480 (= het jaar waarin Memling "leent") is uitzonderlijk nat en koud zodat de oogst tegenvalt. ${ }^{23}$ De winter die op die koude en natte zomer volgt is zo mogelijk nog slechter. Reeds van voor Kerstmis en gedurende minstens 10 weken is het extreem koud met veel sneeuwval zodat zelfs bij heel wat burgers bevriezingsverschijnselen worden vastgesteld..$^{24}$ De toestand is zo erg dat de stad een speciale aankoop van hout doet om grote vuren te stoken op de Burg zodat de "aerme, scamele lieden" zich zouden kunnen warmen "mids den grooter coude ende scrancheit van tijde". ${ }^{25}$ Tot overmaat van ramp is het gedurende de koudste tijd ook nog windstil zodat de windmolens geen koren kunnen malen terwijl de watermolens bevroren zijn. Naast kou lijdt de bevolking ook honger. ${ }^{26}$ Vanaf mei 1481 laat de mislukte oogst van de voorafgaande zomer zich voelen en beginnen de prijzen te stijgen. De stad grijpt in. Vooreerst stuurt

$21 \mathrm{SAB}, \mathrm{nr} .157$ Civiele Sententiën van de Vierschaar, register $1490-92$ f 6 r. "...Omme welcke leenninghen omme te stellene ghecoren hebben ghesijn neghene persoonen ute neghen leden van deser stede. Ende naer dat de poorters ende inwonenden bij hemlieden ghestelt hebben ghesijn de voors leeninghe te doene 70 hebben bij mijnen heeren vander wet zekere wethouders in elc zestendeel gheordonneirt ghezijn de welcke elcken die te leenene ghestelt zijn te zijnen persoone ofte huuse de sommen van dien te kennen ghegheven hebben lastende elcken datte alzo te vulcommene ende te vuldoene..."

$22 \mathrm{SAB}, \mathrm{nr}$ 208, Wezengoederen Sint-Niklaaszestendeel 5de boek, 1467-1490, f 199v. Zie ook de gepubliceerde tekst bij De Vos D.: Memling., p. 411.

23 Despars N.: Chronijcke van den lande ende graefscepe van Vlaenderen (4051492), uitg. De Jonghe J., 2de uitg., deel IV, Brugge, 1842, p. 202. En ook: Dits die excellente cronieke van Vlaenderen, uitgegeven door Willem Vorsterman, Antwerpen, 1531, f 219v.

24 Despars N.: Chronijcke., dl.IV., p. 203.; Excellente Cronicke., f 219v.

$25 \mathrm{SAB}$, stadsrekening $1480-81 \mathrm{f} 165 \mathrm{r}$.

26 Despars N.: Chronijcke., dl.IV., p. 203.; Excellente Cronieke., f 219v. 
het stadsbestuur een boodschapper naar alle kloosters in het Brugse opdat ze God zouden bidden voor goed weer. ${ }^{27}$ Daarbovenop worden enkele protectionistische maatregelen genomen van kracht voor alle aan het Brugse gezag ondergeschikte besturen. ${ }^{28}$ Het stadsbestuur begint ook systematisch zelf graan te kopen om zo een voorraad aan te leggen. ${ }^{29}$ Het mag allemaal niet baten, want in juni 1481 stijgt de graanprijs op de Brugse markt tot de fabelachtige som van $16 \mathrm{~s}$. gr. voor een hoet. ${ }^{30}$ Brugge beleeft trouwens in die tijd de hoogste prijsperiode van de ganse vijftiende eeuw. ${ }^{31}$ In een poging om de prijzen te drukken beslist de stad een deel van haar eigen graan te verkopen aan de nog altijd erg hoge prijs van 11 s. 4 d. gr. per hoed maar gerantsoeneerd tot 2 hoed per persoon. De boeren die op de Brugse markt graan verkopen worden, manu militare, door de burgemeester en scabletters gedwongen hun prijzen eveneens tot op dit niveau te laten zakken. Het komt tot opstootjes en 4 boeren worden gevangen gezet. $^{32} \mathrm{Om}$ het ergste te keren poogt de stad met alle middelen graan te kopen. ${ }^{33}$ Er worden orders geplaatst zowel bij leveranciers uit het Brugse hinterland als bij vreemde kooplui. De leverancies van over zee worden echter bemoeilijkt door de slepende oorlog met Frankrijk. Nadat men op die manier met moeite het hongerseizoen $1480 / 81$ is doorgesparteld, is het leed nog niet geleden want de oogst in de zomer van 1481 mislukt opnieuw, nog maar eens door slechte klimatologische omstandigheden. Het stadsbestuur doet meerdere malen een beroep op goddelijke interventie via de vraag aan de kloosters om gebeden en processies te houden voor "ghetidich weder". ${ }^{34}$

De honger wordt nijpend. Op de begrafenis van Clais van Nieuwenhove werd, zoals gebruikelijk in die tijd, voor het zieleheil van de overledene aan de armen brood uitgedeeld. De toeloop was zo groot dat bij de uitdeling een gedrang ontstond waarin 7 mensen werden doodgetrappeld.

$27 \mathrm{SAB}$, stadsrekening $1480-81 \mathrm{f} 82 \mathrm{v}$.

$28 \mathrm{SAB}$, stadsrekening $1480-81 \mathrm{f} 81 \mathrm{v} ; \mathrm{f} 82 \mathrm{v}$.

$29 \mathrm{SAB}$, stadsrekening $1480-81 \mathrm{f} 83 \mathrm{v}$.

30 Excellente cronieke f 220 v; Despars N.: Chronijcke.,dl.IV., p. 205.

31 Verhulst A.: Prijzen van granen, boter en kaas te Brugge volgens de "slag" aan het Sint-Donaaskapittel (1348-1819) in: Verlinden C.:Dokumenten voor de geschiedenis van prijzen en lonen, XVe-XIXe eeuw, p. 3-70. Zie ook: Sosson J.P.: Les travaux., zie o.m. de grafiek van de prijsevolutie van de hoet haver en tarwe op p. 294.

32 Excellente cronieke f 220v.; Despars N.:Chronijcke., dl. IV., p. 205.

$33 \mathrm{SAB}$, stadsrekening $1480-81$ f $89 \mathrm{r}-89 \mathrm{v}-90 \mathrm{r}$. stadsrekening 1481-82 f $60 \mathrm{r}-60 \mathrm{v}$.

$34 \mathrm{SAB}$, stadsrekening $1480-81 \mathrm{f} 90 \mathrm{r}$.

35 Despars N.:Chronijcke., dl.IV., p.210.;Excellente cronieke., f 222r. 
Het stadsbestuur kijkt niet op een inspanning om zoveel mogelijk het tekort aan graan en de daarmee gepaard gaande hoge prijzen te bestrijden. Er worden boodschappers helemaal tot in Holland gestuurd omdat men vernomen had dat daar graan lag toebehorend aan Duitse kooplieden. ${ }^{36} \mathrm{Om}$ de nood te helpen lenigen verkoopt de stad haar eigen voorraden graan en wordt de beperking wie brood mag bakken tijdelijk opgeheven, zodat in de precaire toestand van het ogenblik ieder die over graan beschikt ook brood mag bakken voor anderen. ${ }^{37}$ Als iemand erin zou slagen graan binnen te brengen beloofde de stad voor iedere 100 hoet een bonus van $5 £$ gr. ${ }^{38}$ De Kerk laat bekendmaken dat de hongerende bevolking in de vastentijd de toestemming krijgt om zuivelprodukten te verbruiken behalve de laatste vier dagen voor Pasen. ${ }^{39}$ De stad schaft ook nog de onrechtstreekse belasting die normaal op voedingsprodukten rust $\mathrm{af}^{20}$, en prest de inwoners die onmiddellijk buiten de stadspoorten in de landelijke gebieden wonen om hun graan op de markt te komen verkopen. ${ }^{1}$ Dit allemaal met maar één doel: de bevolking van de hongerdood redden.

De winter van 1481/82 is opnieuw behoorlijk streng. Maria van Boergondië gaat kort voor haar plotse overlijden, samen met haar hofhouding schaatsen op de dichtgevroren stadsgrachten.

Het zijn vooral vreemde kooplieden, Spanjaarden en Duitsers die gelokt door de premie van $5 £$ gr. per 100 hoet graan, de stad van de uithongering redden in de lente van 1482 . Om het moreel van de bevolking op te vijzelen werd er vanop de halle omgeroepen dat de stad 18771 hoet tarwe en 910 hoet rogge had aangekocht. ${ }^{13}$ De verhoogde activiteit i.v.m. de voedsclbevoorrading, duidelijk af te lezen uit menigvuldige posten in de stadsrekening, sleept zeker aan gedurende het ganse jaar 1482. De stad doet een persoonlijk beroep op de koning van Engeland teneinde zijn bemiddeling te verkrijgen om

$36 \mathrm{SAB}$, stadsrekening $1481-82 \mathrm{f} 65 \mathrm{r}$.

37 Despars N.:Chronijcke., dl.IV., p. 210. In normale tijden mochten allcen de bakkers brood dat in de stad gebakken was, verkopen. Zie daaromtrent SAB nr 120 , hallegeboden 1490/91 f $66 \mathrm{v}$.

38 SAB, stadsrekening 1481-82 f 174v; Despars N.:Chronijcke., dl.IV., p 210; Excellente cronieke f 222 r.

39 Excellente cronieke f $223 \mathrm{v}$.

$40 \mathrm{SAB}$, stadsrekcuing 1481-82 $\mathrm{r} 17 \mathrm{r}$.

$41 \mathrm{SAB}$, stadsrckening $1481-82 \mathrm{f} 65 \mathrm{v}$.

42 Excellente cronicke f $223 \mathrm{v}$. " In desen selven tijt die princesse Marye van Bourgocngien en liet haer niet gheraden noch regieren alsoo sij wel sculdich was van doene maer si liep menich warven spelen up thijs met scaverdijnen ende met scricschoen tusschen der Ghendpoorte ende de Cruuspoorte....".

$43 \mathrm{SAB}$, stadsrekening 1481-82 f $174 \mathrm{v}$. Ook in stadsrekening $1482-83 \mathrm{f} 171 \mathrm{v}-172 \mathrm{r}$. 
Engels graan in Vlaanderen te krijgen ${ }^{44}$ In oktober-november 1482 heeft de stad een hoeveelheid graan gekocht aan de Spaanse koopman Petro Salemano. Niettegenstaande het stadsbestuur beslist om in verschillende schuifjes dit graan met verlies door te verkopen aan de bakkers en de poorters van de stad, stijgt de prijs van een hoet tot de absolute recordhoogte van 16 s.gr. en zelfs bij twee gelegenheden tot $17 \mathrm{~s}$. gr. ${ }^{45}$ Wanneer bekend wordt dat tegen de verordening van een plakkaat in, uit de aan Brugge ondergeschikte gebieden toch graan zou zijn uitgevoerd, laat de stad dit onmiddellijk onderzoeken. ${ }^{46}$

Vanaf 1483 lijkt de ergste hongersnood achter de rug te zijn en concentreert de aandacht zich op het conflict dat sinds het overlijden van Maria van Boergondië einde maart 1482, in een aanvangsfase eerder aarzelend, maar vanaf 1483 in volle hevigheid was uitgebarsten. De inzet was de bestuurlijke voogdij over de minderjarige troonopvolger. Dit conflict tussen Maximiliaan van Oostenrijk aan de ene kant en de Drie Leden van Vlaanderen samen met enkele vooraanstaande edelen aan de andere kant, neemt geleidelijk de allure van een echte burgeroorlog aan en blijft duren tot juni 1485 . $^{47}$ Dat een dergelijk gewapend conflict niet zonder extra financiële lasten voor de meeste burgers wordt uitgevochten laat zich raden.

Het effect is cumulatief want die interne oorlog volgt op een oorlog met Frankrijk die al uitgebroken was sinds de troonopvolging van Maria van Boergondië in 1477 en begint op een ogenblik dat de boven beschreven hongersnood nauwelijks verholpen is. Vanaf 1480 beginnen dus diverse negatieve factoren samen te komen zodat de levensomstandigheden voor de doorsnee Brugse burger merkelijk moeilijker worden.

Hoe heeft het gezin Memling die troebele hongerjaren tegen de achtergrond van oorlog en burgeroorlog op financieel vlak opgevangen ?

Verschaffen de bronnen de mogelijkheid om er achter te komen wat Memling met zijn schilderijen verdiende ? We weten dat hij in $1478 / 79$ betaald wordt voor het schilderen van twee luiken van een

$44 \mathrm{SAB}$, stadsrekening $1482-83$ f $167 \mathrm{r}$.

$45 \mathrm{SAB}$, stadsrekening $1482-83 \mathrm{f} 175 \mathrm{r}$.

$46 \mathrm{SAB}$, stadsrekening $1482-83 \mathrm{f} 64 \mathrm{r}-\mathrm{v}$.

47 Blockmans W.P.: Autocratie ou polyarchie? La lutte pour le pouvoir politique en Flandre de 1482 à 1492, d'après des documents inédits, in: Handelingen van de Koninklijke Commissie voor Geschiedenis, 140, (1974). p.257-368. Passim. 
retabel in de kapel van het gilde der librariërs in de Eekhoutabdij te Brugge. Hiervoor ontvangt hij volgens de rekeningen van het gilde in totaal $4 £ 2$ s. gr. Laten we niet vergeten dat hiervan de verf en andere onkosten moeten afgenomen worden. Die luiken zijn niet bewaard, zo dat we niet weten hoe groot ze waren en dus hoeveel tijd en materiaal er nodig was. ${ }^{18}$ Die gegevens zijn bijzonder summier maar door ze te gebruiken als vergelijkingsmateriaal wordt toch een niet onbelangrijk feit naar boven gebracht.

In de stadsrekeningen duikt in de besproken periode, regelmatig de naam op van de schilder Fransoys vande Pitte. Hij knapt voor de stad allerlei schildersklussen op van de meest diverse aard. Zo maakt Fransoys vande Pitte 'patronen', zoals ze in de tekst genoemd worden, dit zijn tekeningen die moeten dienen als voorstudies om beelden te snijden. Hij tekent 'patronen' voor een beeld van Onze-LieveVrouw in een tabernakel, van Karel de Stoute, Maria van Boergondië en Maximiliaan van Oostenrijk en ook nog voor een beeld van de heilige Catharina. Daarnaast schildert hij nog vijftig wapenschildjes van de stad Brugge om aan toortsen te bevestigen. Voor die vijf tekeningen en die schildjes betaalt de stad hem $2 £ 16$ s. $^{49}$ In datzelfde jaar schildert Fransoys vande Pitte ook nog in opdracht van de stad 5 banieren die zullen gebruikt worden door de 5 minnestrelen van de stad. Twee banieren moeten bevestigd worden aan trompetten en de drie andere zijn voor de pijpers zodat we ook een idee krijgen van de grootte van die vaandels. Hiervoor krijgt hij $2 £ 6 s$ gr. $^{50}$ Wanneer de Duitse keizer Frederik en zijn zoon Maximiliaan van Oostenrijk hun triomfantelijk intrede in Brugge houden wil de stad natuurlijk zo goed mogelijk te voorschijn komen en krijgt o.a. Fransoys vande Pitte de opdracht drie grote schilden te schilderen die aan de Kruispoort zullen worden opgehangen en ook nog eens drie schilden die de Grote Markt zullen helpen versieren. Over de schilden op de Grote Markt geeft de rekening nadere specificaties. Het zijn drie wapenschilden en er wordt ondermeer een kroon en het Gulden Vlies op geschilderd, zodat we kunnen vermoeden dat het de wapenschilden van de keizer, van Maximiliaan en waarschijnlijk van de stad zelf betreft. Daarenboven heeft hij ook nog 150 schilden met het stadswapen beschilderd. Hoe groot die 150 schilden waren is niet bekend. Voor dit alles ontvangt hij $6 £^{51}$

$49 \mathrm{SAB}$, stadsrekening $1485-86$ f $159 \mathrm{v}$

$50 \mathrm{SAB}$, stadsrekening $1485-86$ f $172 \mathrm{r}$.

51 SAB, stadsrekening $1485-86 \mathrm{f} 177 \mathrm{r}$. 
In 1480 krijgt de schilder Jan Fabyaen de opdracht van de broederschap van Onze-Lieve-Vrouw-ter-Sneeuw om een nieuw vaandel te schilderen en krijgt daarvoor $2 £$ gr.

Zoals hierboven aangehaald krijgt Memling $4 £ 2$ s voor het schilderen van een retabel. Dit betekent dat mathematisch bekeken, één retabelluik van Memling door de tijdgenoten financieel niet hoger werd gewaardeerd dan een vaandel beschilderd door Jan Fabyaen of vijf vaantjes om de muziekinstrumenten van de minnestrelen te versieren, beschilderd door Fransoys vande Pitte. Ook de andere schilderwerken van Fransoys vande Pitte bevestigen de orde van grootte waarin de financiële vergoeding van schilders, Memling niet uitgezonderd, moet gezien worden. Wij, in de huidige tijd, plaatsen het werk van Memling kwalitatief heel wat hoger dan die andere hier aangehaalde schilderingen, zelfs zonder dat we die laatste gezien hebben. Als we vanuit die artistieke waardering aannemen dat de financiële vergoeding voor Memling ook hoger was, dan is dit een anachronisme. In 1473 werd het Laatste Oordeel en een ander onbekend retabel van Memling bij de verscheping van Brugge naar Florence, door zeerovers gekaapt. Portinari, die verantwoordelijk was voor de vracht vroeg schadeloosstelling en eiste voor de twee altaarstukken een som van $100 £ \mathrm{gr} .{ }^{53}$ Het Laatste Oordeel is een bijzonder groot schilderwerk terwijl het onbekend retabel natuurlijk niet kan ingeschat worden. Het spreekt voor zich dat dit bedrag van $100 £$ gr. niet ernstig kan genomen worden want anders zou men vandaag de dag alle schadeclaims die bij een verzekeringsmaatschappij binnenkomen moeten beschouwen als de objectieve waarde van het geleden verlies.

De bedenking die hier kan gemaakt worden is natuurlijk of de som die het gilde van de librariërs voor het retabel betaald heeft wel representatief was voor het ganse oeuvre van Memling. Wij denken van wel. Immers, wanneer vrouw Tanne in 1486 overlijdt en dit is dan nog net voor dat het echt financieel slecht begint te gaan in Brugge, bedraagt het ganse roerende bezit van Memling $24 £$ gr.

Voor alle opdrachten samen die hij in de loop van het jaar 1485-86 voor de stad heeft uitgevoerd ontvangt Fransoys vande Pitte de som van $79 £ 2 \mathrm{~s} .{ }^{54}$ Hij werkt niet uitsluitend in stadsdienst zoals de overige

52 Rijksarchief Brugge, archief Onze-Lieve-Vrouwekerk, broederschap Onze-LieveVrouw-ter-Sneeuw, rekening 15 aug. 1480- 15 aug. $1481 \mathrm{f} 200 \mathrm{r}$.

53 De Vos D.:Memling., p.25-26.

$54 \mathrm{SAB}$, stadsrekening $1485-86$ f $159 \mathrm{v}, \mathrm{f} 169 \mathrm{v}, \mathrm{f} 172 \mathrm{r}, \mathrm{f} 177 \mathrm{v}$. 
stadsrekeningen aantonen waar hij soms niet of nauwelijks in voorkomt. We mogen aannemen dat zijn jaarinkomen in 1485-86 door andere opdrachten misschien nog hoger zal geweest zijn dan die $79 £$ 2 s. Welnu na ongeveer 20 jaar de vele prachtige kunstwerken geschilderd te hebben die wij kennen heeft Memling een bedrag overgespaard die hooguit één vierde bedraagt van wat Fransoys vande Pitte in één jaar als omzet verdiend heeft. Dat de bezoldiging die Fransoys vande Pitte ontvangen heeft meer dan waarschijnlijk de arbeid vergoedt van een gans atelier, maakt voor ons standpunt nauwelijks verschil uit.

Toch vertegenwoordigen die $4 £ 2$ s.gr. die hij ontvangt voor het retabel ongeveer het inkomen van 4 maanden arbeid van een meesterambachtsman uit het bouwvak. ${ }^{55}$ Als we het bewaarde oeuvre van Memling in acht nemen, dan kan hij geen 4 maanden aan een retabel gewerkt hebben zodat zijn beroepsinkomen toch hoger moet ingeschat worden dan die van de doorsnee collega meesterambachtsman.

Nadat zijn vrouw Tanne gestorven is worden op 10 september 1487 de bezittingen van Memling geregistreerd bij de wezengoederen van de stad in het Sint-Niklaaszestendeel, teneinde de rechten van de wezen veilig te stellen. ${ }^{56}$ Tanne is al minstens een jaar vroeger overleden want reeds op 11 september 1486 werden de voogden over de kinderen aangeduid..$^{57}$ De geregistreerde bezittingen weerspiegelen de situatie zoals ze bevroren werd op het moment van het afsterven van Tanne. Op dat ogenblik bezat het gezin Memling twee huizen naast elkaar in de huidige Sint-Jorisstraat en een klein gebouwtje met een poortje, daarachter gelegen, uitgevend in de Jan Miraalstraat. ${ }^{58}$ Eén van de huizen is al eigendom van Memling in 1466-67. Op dat ogenblik heeft hij de verschuldigde grondrente van het huis voldaan

55 Zie noot 19. Het ambacht van de beeldemakers-madelaars, waar de schilders deel van uitmaakten, was op haar beurt een onderdeel van het lid van de 17 neringen die in hoofdzaak de ambachten uit het bouwvak bundelde.

56 SAB, nr 208, Wezengoederen Sint-Niklaaszestendeel 5de boek , 1467-1490, f 199v. Zie ook de gepubliceerde tekst bij De Vos D.: Memling., p. 411.

57 SAB, nr 205 Wezerij voogdijschappen Sint-Jakobszestendeel, 1485-1497, f 170r. "Lodewijc de Valkenaere de bocraenvaerwere ende Dieric vanden Gheere de goudsmet voogden van Hannekin, Cornelekin ende Claykin meesters Jans Memmelinc scilders kinderen ex Tanne uxore. Actum XI in septembre anno LXXXVI. Present scepenen Bave, Abinsvoorde." De datering anno 86 is geen verschrijving van de scribent wat gemakkelijk zou gekund hebben. Immers de voorafgaandelijk post is gedateerd 7 september 1486 en na de voogden van Memlings kinderen worden opnieuw voogden geregistreerd op 2 oktober 1486.

58 De Vos D.: Memling., p. 411-412. 
aan de kerkfabriek van Sint-Donaas. ${ }^{59}$ De ontvanger noteert dat Memling in een "groot stenen huis" woont. Vooral dit 'groot' moet men waarschijnlijk eerder zien als een subjectieve appreciatie van de ontvanger van de rente, want de beschrijving in het register van wezengoederen geeft veeleer de indruk dat het huis van de gebuur, dan nog maar enkel aangehaald als middel ter situering van de huizen van Memling, minstens even groot lijkt als de twee huizen samen. De inboedel wordt, in geld, geschat op $24 £$ gr. De helft hiervan wordt nu dus eigendom van de wezen.

Om niet te moeten overgaan tot verkoop van delen van het meubilair of andere roerende zaken, zal Memling als vader dit bedrag beheren en waarborgen met zijn deel van het onroerend goed."

Technisch gesproken bezit Hans Memling na het overlijden van zijn vrouw Tanne nog slechts de helft van zijn vroeger bezit. In 1486 is het roerend en onroerend bezit van Memling gehalveerd in vergelijking met 1480 . Is dit misschien de verklaring waarom de weduwnaar niet langer beschouwd wordt als welstellend genoeg om de stad geld voor te schieten ? Dit is zeker niet de normale handelwijze. Er zijn meerdere gevallen bekend waarbij, na sterfgeval, de goederen onder de erfgenamen verdeeld worden en de weduwe later toch weer in de lijsten van de geforceerde leningen terug te vinden is.

Dat Memling ook niet over "liggend" kapitaal beschikte om te investeren wordt door meerdere bronnen bevestigd. Jaar na jaar worden tientallen, in totaal honderden, transacties genoteerd in de stadsrekeningen van de aan- en verkoop van stadsofficies van allerlei slag. Zo'n stadsofficie moet in de eerste plaats gezien worden als een goede geldbelegging, maar ook hier is nergens, gedurende de ganse periode van zijn verblijf in Brugge, de naam Memling van dichtbij of veraf te bespeuren, alhoewel in heelwat gevallen de opkopers ambachtslui zijn.

In moeilijke tijden probeert de stad Brugge aan geld te geraken via het openbaar uitschrijven van los- of lijfrenten. Tussen 1482 (einde van de hongersnood) en 1487 (het moment van de boedelbeschrijving) heeft de stad Brugge die langzaam wegzinkt in een financieel

59 Zie De Vos D.:Memling., status quaestionis, p. 407.

60 Zie noot 56.

61 De neerslag van de verkoop door de stad van stadsofficies kan men om zo te zeggen jaarlijks geboekt vinden in de respectieve stadsrekeningen. Zie ook Vandewalle A.: De stadsofficiën van Brugge: openbaar ambt of commercie XVdeXVIIde eeuw, in: Macours f.: Cornua legum. Actes des journées internationales d'histoire $d u$ droit et des institutions. 1986. Antwerpen, 1987, p. 217-225. 
moeras, maar liefst 7 maal een uitgifte geplaatst van dergelijke los- en lijfrenten, voor een bedrag dat $3000 £$ gr overschrijdt. In de stadsrekeningen zijn meerdere tientallen folio's gevuld met de namen van honderden burgers die zijn ingegaan op de soms erg lucratieve aanbiedingen, maar ook hier ontbreekt de naam Memling. ${ }^{62}$ Laten we duidelijk zijn, het gaat hier en trouwens ook bij de verkoop van de stadsofficies om gesloten lijsten. Dus als een naam daar niet op voorkomt m.a.w. 'ontbreekt' dan is het ook absoluut zeker dat de persoon in kwestie niet heeft deelgenomen.

In de staat van goed is geen enkel spoor te vinden van welke aard ook, die op een andere vorm van inkomen, niet afkomstig van schilderijen, zou kunnen wijzen.

De beschrijving van het bezit van het gezin Memling na de dood van de moeder Tanne schat het roerend bezit op $24 £$ gr. De helft hiervan wordt geërfd door de kinderen en de andere $12 £$ gr blijft eigendom van de vader. Wanneer de schilder zelf overleden is in 1494 wordt het bezit opnieuw geschat en nu blijft van het roerend bezit nog slechts $8 £$ gr over of een vermindering met $33 \%$ t.o.v. de som in $1486 / 87 .^{63}$

\section{Hans Memling: sociaal.}

Precies zoals van Memling wordt aangenomen dat hij een financieel bemiddeld man was, zo wordt eveneens nogal gemakkelijk aanvaard dat hij zich in sociaal hogere kringen te Brugge zou bewogen hebben. Het argument daarvoor kijkt ons aan vanuit zijn schilderijen nl. de rijke en vooraanstaande opdrachtgevers. Hier dient nochtans opgemerkt dat een beroepsrelatie niet noodzakelijk sociale omgang impliceert.

In 1472/73 wordt Memling opgenomen in het broederschap van Onze-Lieve-Vrouw-ter-Sneeuw. ${ }^{64}$ Heel wat vooraanstaande burgers

62 Jaar na jaar worden de terugbetalingen op die losrenten en lijfrenten in de stadsrekeningen genoteerd. Een volledig overzicht van alle burgers die terugbetaald worden over de periode 1480-1487 kan men terugvinden in SAB, stadsrekening $1 / 3-31 / 8 / 1488$ f $73 \mathrm{v}$ e.v.

$63 \mathrm{SAB}, \mathrm{nr}$ 208, Wezengoederen Sint-Niklaaszestendeel 5de boek ,1467-1490, f 199v. Zie ook de gepubliceerde tckst bij De Vos D.: Memling., p. 411.

64 Rijksarchief Brugge, archief Onze-Lieve-Vrouwekerk, broederschap Onze-LieveVrouw-ter-Sneeuw, rekening 1473-1474, f. 129. Gepubliceerd door Schouteet A.:Nieuwe teksten betreffende Hans Memling, in: Belgisch tijdschrift voor Oudheidkunde en Kunstgeschiedenis, 24 (1955), p. 81-84. Zie ook: De Vos:Memling., p.408. 
waren eveneens lid van dit broederschap zodat we ons kunnen afvragen of misschien via dit lidmaatschap een zeker sociaal prestige op Memling afstraalde?

In die tijd bestonden er in Brugge zeer veel gilden of religieuse broederschappen. ${ }^{65} \mathrm{Om}$ zo te zeggen ieder ambacht, en zelfs onderdelen van ambachten, had naast de organisatie die de arbeidsrelaties van het ambacht regelde een gilde, een soort religieuze zijtak. De meeste zijkapellen van de grote Brugse kerken werden "verhuurd" aan dergelijke gilden of broederschappen. Dat de broederschap van Onze-Lieve-Vrouw-ter-Sneeuw, exclusiever zou zijn dan de anderen kan niet aangetoond worden. Als er bijna 1000 mensen lid van het broederschap waren kan men dit nog nauwelijks exclusief noemen. ${ }^{66}$ Iedere gilde zal wel enkele vooraanstaande burgers onder zijn leden geteld hebben. Zo treft men onder de leden van de gilde van den Drogen Boom Filips de Goede, Isabella van Portugal, Karel de Stoute en zijn tweede vrouw Isabella de Bourbon, de grote bastaard van Boergondië, Lodewijk van Gruuthuuse en een ganse reeks edelen van de plaatselijke families zoals Adornes, van Nieuwenhove e.a. en ook de schilders Petrus Crhistus en Gerard David aan. ${ }^{67}$ En ook was bijvoorbeeld schout Pieter Lanchals, één van de rijkste burgers van de stad en favoriet van Maximiliaan van Oostenrijk, lid van meerdere broederschappen. Hij liet in zijn testament opnemen toen hij in 1488 door de Bruggelingen ter dood veroordeeld was:"....dat men betale de doodsculden van alle ghilden daer inne dat ic ben." ${ }^{n 6}$

De broederschap van Onze-Lieve-Vrouw-ter-Sneeuw telt inderdaad een aantal vooraanstaande poorters in haar rangen, maar dat de connectie met de broederschap voor Memling iets speciaals zou betekend hebben wordt nog verder gerelativeerd als men weet dat bv. ook een andere schilder, meer bepaald Jan Fabyaen, eveneens lid was

65 Om maar enkele voorbeelden aan te halen. Van Quathem K.: Het broederschap van de schoenmakers of "elsenaars" te Brugge, in: HGG, 133, (1996). Ook nog Hodüm A.: Oorsprong van de broederschap van O.L.Vrouw Presentatie in de SintJacobskerk te Brugge, in: $H G G, 91,(1954)$ p.109. Er zijn meerdere publicaties verschenen over de broederschappen en de gilden, alhoewel sommige daarvan uit de vorige eeuw dateren. Omdat het onderwerp voor ons betoog slechts een exemplarische waarde heeft en om het notenapparaat niet nodeloos te verzwaren zullen we het hier bij die enkele voorbeelden laten.

66 De Vos D.: Memling., p.36.

67 Strohm R: Muzikaal en artistieke beschermheerschap in het Brugse Ghilde vanden Droghen Boome, in: Biekorf, 83,(1983) p. 11-12. Zie ook De Schodt A: Confrérie de Notre-Dame de l'Arbre Sec, in: HGG, 28 (1876-77) p. 141-187.

68 Gailliard J: Inscriptions funéraires et monumentales de la Flandre Occidentale avec des données historiques et généalogiques. Arrondissement de Bruges. Bruges, 1861. Tome I, p. 275. 
en dat de genoemde Jan Fabyaen van het broederschap de opdracht krijgt een vaandel te beschilderen. ${ }^{6 y}$

$\mathrm{Na}$ het overlijden van Tanne in 1486 worden de materiële belangen van de kinderen behartigd door twee voogden bij wet aangesteld. ${ }^{70}$ De ene is Lodewijc de Valkenaere "de bocraenvaerwere" en de andere is Dieric vanden Gheere "de goudsmet". Lodewijc de Valkenaere maakte als bocraenverver deel uit van het ambacht van de culcstickers. Lodewijc is tweemaal aangeduid als vinder in het ambachtsbestuur nl. in 1477 en nog eens in de revolutionaire wetsvernieuwing van 12 februari 1488. ${ }^{71}$ Maar anderzijds heeft Lodewijc de Valkenaere aan geen enkele geforceerde lening deelgenomen. Rijk zal hij dus zeker niet geweest zijn. De goudsmid Dieric vanden Gheere, de andere voogd, wordt in tegenstelling tot Lodewijc in 1487 wel getaxeerd voor de geforceerde lening. Hij "leent" $1 £$ gr. samen met nog 526 andere burgers op een totaal aantal ontleners van $954 .{ }^{72}$ Dus Dieric wordt door zijn tijdgenoten beschouwd als meer dan doorsnee begoed, maar hij behoort evenmin tot de echt financiële top van de stad. In september 1493, het laatste levensjaar van Memling, wordt Dieric vanden Gheere opgenomen als vinder in het ambacht van de goudsmeden. ${ }^{73}$ Uit dit alles mag blijken dat voor Memling de voornaamste "vrienden ende magen" zoals ze in die tijd genoemd werden, eerder in de sfeer van de ambachtslui moeten gezocht worden.

\section{Hans Memling: politiek.}

De overwinning van Maximiliaan van Oostenrijk in zijn conflict met de grote Vlaamse steden cind juni 1485, zorgde voor een korte periode van relatieve rust, maar de ontevredenheid bleef smeulen. De overwinning was er wel, maar tot een echte pacificatie was het nooit gekomen. Een te voorspellen, nieuwe uitbarsting van geweld grijpt

69 Rijksarchief Brugge, archief Onze-Lieve-Vrouwekerk, broederschap Onze-LieveVrouw-ter-Sneeuw, rekening 15 aug.1480- 15 aug.1481 f 200r. "Item betaelt Jan Fabyaen de schildere voor het maken van een nyeuwe vane die hij leveren zal tusschen dit ende kerstmesse 2 £ gr.".

$70 \mathrm{SAB}$, nr 205 Wezerij voogdijschappen, deel 1485-97 Sint-Jakobszestendeel f $170 \mathrm{r}$.

71 SAB, wetsvernicuwingen $1468-1501$ respectievelijk $f 91 \mathrm{v}$ en $\mathrm{f} 175 \mathrm{r}$.

$72 \mathrm{SAB}$, stadsrekening 1480-81 f $188 \mathrm{v}$ en volgende.

73 Vandewalle A.: De besturen van het ambacht van de goud- en zilversmeden, 13631796, in: Marechal D.:Meesterwerken van de Brugse edelsmeedkunst, Brugge, 1993, p.418. Dieric vanden Gheere wordt later nog vinder in 1498, 1500 en 1505 maar dan is Memling al overleden en is dit niet zo relevant voor deze bijdrage. 
plaats begin februari 1488 wanneer de Bruggelingen menen dat Maximiliaan van Oostenrijk, die op dat ogenblik in de stad verbleef, een poging had ondernomen om samen met enkele aanhangers uit de stedelijke bevolking, de stadspoorten open te zetten om op die manier zijn huurlingen toe te laten de stad militair te bezetten. ${ }^{74}$ De reactie van de ambachtslui is ongemeen hevig. Op aanstoken van de Gentenaars arresteren zij Maximiliaan en geven hem huisarrest in Cranenburg op de Grote Markt. De sfeer is bijzonder grimmig. De revolterende ambachtslieden die gemobiliseerd op de Grote Markt staan, weigeren ieder contact met de zetelende schepenen die sinds 2 september 1487 in functie waren en natuurlijk uit aanhangers van Maximiliaan bestonden. ${ }^{53}$ In naam van de minderjarige hertog en de Drie Leden van Vlaanderen werd op 12 februari 1488 een nieuwe, we mogen gerust stellen revolutionaire schepenbank aangesteld en terzelfdertijd werden ook de ambachtsbesturen vervangen door revolutionair gezinde elementen waar de aanhangers van Maximiliaan uit weggezuiverd waren. ${ }^{76}$ Maximiliaan blijft tot in mei in gevangenschap terwijl het opstandige Brugge op een geweldadige manier afrekent met die leden uit de omgeving van Maximiliaan die verantwoordelijk worden geacht voor de conspiratie waarbij ook allerlei andere materies die gevoelig liggen, zoals corruptie, weer worden bovengehaald. De volkswraak neemt onrustbarende vormen aan. Vroegere hoogwaardigheidsbekleders en notabelen worden op de Grote Markt ten aanschouwe van de gemobiliseerde ambachten op een afgrijselijke manier gefolterd en een aantal van hen worden ook onthoofd. ${ }^{77}$ Eèn is zelfs zo verzwakt door de foltering dat hij gezeten in een zetel het hoofd wordt afgeslagen. Op de hoofden van diegenen die de volkswoede over zich hebben gehaald en er in geslaagd waren te vluchten, worden zeer grote sommen geld gezet. ${ }^{78}$ Eenmaal bevrijd, begint Maximiliaan opnieuw de opstandige steden te onderwerpen. Dit heeft alvast voor gevolg dat de Brugse bevolking in twee kampen verdeeld is. Voor de enen weegt de trouw en gehoorzaamheid aan de gekroonde vorst duidelijk door, voor anderen is Maximiliaan een meinedige, die de plechtige eed die hij gezworen

74 Wellens R.: La révolte brugeoise de 1488, in: HGG. 102,(1965) p. 5-52.

75 Diegerick I.: Correspondance des magistrats d'Ypres pendant les troubles de la Flandre sous Maximilien, Bruges, 1853, p. 96.

$76 \mathrm{SAB}$, Wetsvernieuwingen 1468-1501 f $179 \mathrm{r}$, zie ook SAB, stadsrekening maartaugustus $1488 \mathrm{f} 130 \mathrm{r}$.

77 Zie o.a. Vanden Bussche E.: Un épisode des troubles sous Maximilien. Interrogatoire de Jacques de Ghistelles, in: La Flandre, 2 (1868-69) p.186 e.v.

78 Custis C.: Jaerboecken der stad Brugghe, tweede uitgave, 2 dln.,Brugge, 1765, p.106 en p. 128. Despars N.: Chronijcke.,IV., p. 327. 
had bij zijn vrijlating en waarbij hij vergiffenis schonk voor het feit van zijn gevangenschap, heeft gebroken en dus onbetrouwbaar is en zeker niet langer moet gehoorzaamd worden. Het is hier niet de plaats om een gedetailleerd verslag te geven van de vele gruwelen en overlast voor de bevolking en de ingreep op het dagdagelijkse leven dat door dit conflict wordt veroorzaakt ${ }^{79}$ Het ligt alleen maar in onze bedoeling aan te tonen dat het ongeloofwaardig is aan te nemen dat iemand binnen de Brugse stadsmuren door de gebeurtenissen die in gans Europa weerklank vonden, onberoerd zou gebleven zijn. ${ }^{80}$ Eén zaak lijkt wel vast te staan namelijk dat het grootste deel van de Bruggelingen een actief standpunt in het conflict hebben ingenomen, en zoals de kroniekschrijver beweert, Monetaan of Philippine waren, respectievelijk aanhanger van Maximiliaan van Oostenrijk ofwel van de minderjarige aartshertog Filips de Schone. ${ }^{81}$ De radicalisering in de relaties tussen de Brugse poorters wordt door vele kleine gebeurtenissen merkbaar. Op het einde van december 1488 vluchten een aantal aanhangers van Maximiliaan uit de stad. Zij hebben een list moeten gebruiken om buiten de stadspoorten te geraken. Niettegenstaande een hallegebod dit uitdrukkelijk eist, weigeren ze terug te komen. Zelfs de dreiging van zware boete kan hen niet van mening doen veranderen. ${ }^{82}$ Opnieuw heerst er honger, maar ditmaal zijn de oorlogsomstandigheden verantwoordelijk. ${ }^{83}$ Opnieuw legt de stad voedselvoorraden aan, maar de vijand omsingelt de stad en geleidelijk wordt de toevoer van voedsel afgesneden. ${ }^{84}$ Heelwat Bruggelingen worden door gebrek gedwongen de hongerende stad

79 Wellens R.: La révolte., passim.

80 Custis: Jaerboeck., p. 124. Op 3 maart werd vanop de halle een brief van de zeven keurvorsten van het keizerrijk voorgelezen waarin ze de Bruggelingen waarschuwden i.v.m. de houding die ze zouden aannemen ten aanzien van Maximiliaan van Oostenrijk.

81 Custis:Jaerboeck. p. 179. “..dat de Bruggelingen malkander geensins en betrauwden, en onderlinge oncenig wacren; een groot deel, het welcke den Roomsch Koning nog genegen was, wierd Monetaenen genaemt, en de andere, onder den schijn van den jongen Hertog te beschermen, noemden sig Philippinen."

82 Despars N.:Chronijcke., dl.IV., p 428."..Dit spel greyde dieversche notable poorters ende inghesetenen vander stede van Brugghe zo over qualick, dat zy zom, van grooter vreese ende zom uyt goeder joonste, die zy totten roomsch coninck droughen, secretelick haerlieder veerden liepen; dies wierden zy alle ghelijck bij halleghebode inne ghedacht ende ten rechtstame omtboden..", zie ook Custis:Jaerboeck. p. 176.

83 Despars N.:Chronijcke., dl.IV., p. 476. De graaf van Nassau heeft de verbinding Brugge-Sluis kunnen doorbreken zodat om zo te zeggen geen voedsel nog tot Brugge geraakt.

$84 \mathrm{SAB}$, stadsrekening maart-aug. $1488 \mathrm{f} 31 \mathrm{v}$ e.v. Zie in verband met de hongersnood:Walter Prevenier/Wim Blockmans:De Bourgondische Nederlanden. Antwerpen, 1983, p.61 e.v. 
te verlaten. Het stadsbestuur stemt er mee in mits ze zich niet aansluiten bij de vijand. ${ }^{85}$

Tijdens een schermutseling waar het Brugs leger bij betrokken is, worden de twee kapiteins van de stad en twee andere vooraanstaande Bruggelingen gevangen genomen. Hun vrijheid kunnen ze herkrijgen mits het betalen van de niet onaardige lossom van $900 £$. Het stadsbestuur heeft, zonder de bevolking te raadplegen het losgeld betaald en tot overmaat van ramp worden de gijzelaars niet vrijgelaten zodat opnieuw het wantrouwen de kop opsteekt dat er weer iets niet helemaal in de haak is. De boze ambachtslui lopen onmiddellijk weer in de wapens en komen op de Grote Markt de schepenen luidop beschuldigen dat ze allen Monetanen en verraders geworden zijn. Ergere gevolgen blijven uit omdat juist op dat moment het goede nieuws de stad bereikt dat belangrijke Franse troepenversterkingen in Ieper zijn aangekomen.

Na het sluiten van de vrede van Damme in 1490 is de aanvoer van voedsel weliswaar vrij, maar krijgen de Bruggelingen een loodzware financiële nasleep van de vijandelijkheden te dragen. Niet alleen voedsel ontbreekt. De ganse levenssfeer in de stad is op dat ogenblik chaotisch en desastreus. Zo is het bijvoorbeeld een traditie dat de stadsmagistraat tweemaal per jaar van stadswege ambtskledij krijgt, éénmaal bij de aanvang van de ambtstermijn en dan zomerkleren in mei. Welnu, in mei 1490 is er geen "laken" meer in de stad, zodat de stadsmagistraat in geld moet vergoed worden ${ }^{87}$ Er kan hier met reden de vraag gesteld worden als in de staat van totale ontbering waarin de stadsbevolking verkeerde, waarin de stedelijke overheid er zelfs niet meer in slaagde voor zichzelf een toch in normale omstan-

85 Despars N.:Chronijcke.,dl.IV., p. 483. “..zoude mueghen vertrecken met kennessen van zaken, die welcke duer die overgroote dierste ende sobre neeringhe niet langher verdraghen nochte gheerden en consten,...in zulcker wijs dat mender dienvolghende wonderlicke veel schamele menagien zach tallen poorten uyttrecken, die welcke anders van puerder honghere ende ghebreke zouden hebben moeten vergaen.,"

86 Custis:Jaerboeck., p. 180.

$87 \mathrm{SAB}$, stadsrckening 1489-90 f $50 \mathrm{r}$ "Item betaelt Joos van Wulfsberghe als buerchmeester inde stede van meester Anth de Witte voor de dhelt van zijn saysoen laken te zinen ancommene in ghelde mids dat laken niet goelicx te crijghen en was $3 f$ 15 s 10 d". SAB, Wetsvernieuwingen 1467-1501 f 184r. Mecster Anthuenis de Witte was sinds 18 januari 1490 verkozen tot burchmeester van den Courpse. Tijdens de ambtstermijn dic cindigde op 9 december 1490 sterft hij en wordt hij op een niet nader gespecifieerde dag opgevolgd als burchmeester door Joos van Wulfsberghe. In de boven aangehaalde stadsrekening is Joos van Wulfsberghe niet de enige functionaris die in plaats van kledij geld krijgt en telkens wordt vermeld dat kledij schaars is. 
digheden ruim aanwezig artikel als textiel aan te schaffen, in hoeverre de stad dan nog beschikte over de noodzakelijke voorraden om bijvoorbeeld de kunstschilders normaal aan het werk te houden ?

Zoals hierboven beschreven leven de Bruggelingen sinds begin 1488 in een stad waarbij de belangengroep die de macht overgenomen heeft, de politieke tegenstanders, al dan niet via een justitiële actie, fysisch uitgeschakeld. De Brugse burgers leven in een sfeer van onderling wantrouwen en verraad met daar boven op hongersnood en extra financiële lasten. In die omstandigheden bereikt de politieke polarisatie extreme vormen. Wij konden dan ook niet geloven dat Memling in volmaakte isolatie, in een soort ivoren toren, alleen maar schilderijen zat te maken op bestelling van cliënten en dat de vaak turbulente gebeurtenissen rondom hem, helemaal zonder invloed op zijn werk zouden gebleven zijn. We menen een aanwijzing in het werk van Memling te hebben gevonden waar de schilder zijn eigen politieke voorkeur kenbaar maakt.

Het werk in kwestie is het Ursulaschrijn dat door Memling geschilderd werd in opdracht van het Sint-Janshospitaal te Brugge en dat op de feestdag van de heilige Ursula, op 21 oktober 1489, werd ingewijd. ${ }^{88}$ Hoelang aan zo'n schrijn werd gewerkt kunnen we slechts gissen, maar gelukkig is dit voor onze interpretatie niet echt bepalend omdat de gebeurtenissen van invloed plaatsvinden vanaf einde januari 1488 en zeker het ganse jaar 1489 voortduren, zoals hierboven aangetoond, en dus zeker samenvallen in de tijd met de uitvoering van het werk. In de sfeer van totale oorlogvoering die toen heerste wordt je als Bruggeling bijna gedwongen partij te kiezen.

De huidige interpretatie van het zesde tafereel van het Ursulaschrijn stelt de kunsthistorici inderdaad voor enkele raadsels. Het tafereel stelt de moord op de heilige Ursula en haar gezelschap door de Hunnenkoning voor. ${ }^{89}$ Memling heeft in dit laatste tafereel een eigentijds element binnengebracht door tussen het gevolg van de heilige Ursula twee tijdgenoten, aan hun kledij herkenbaar, af te beelden. H. Lobelle heeft vanuit een gans andere denkpiste de hypothese naar voren geschoven dat die twee burgers Memling zelf en zijn inmiddels overleden vrouw Tanne zouden kunnen zijn. Voor onze interpretatie is het al voldoende dat het twee eigentijdse

88 Zie De Vos D.: Memling., p. 301.

89 Die ganse problematiek wordt behandeld door De Vos D.:Memling., p. 300. 


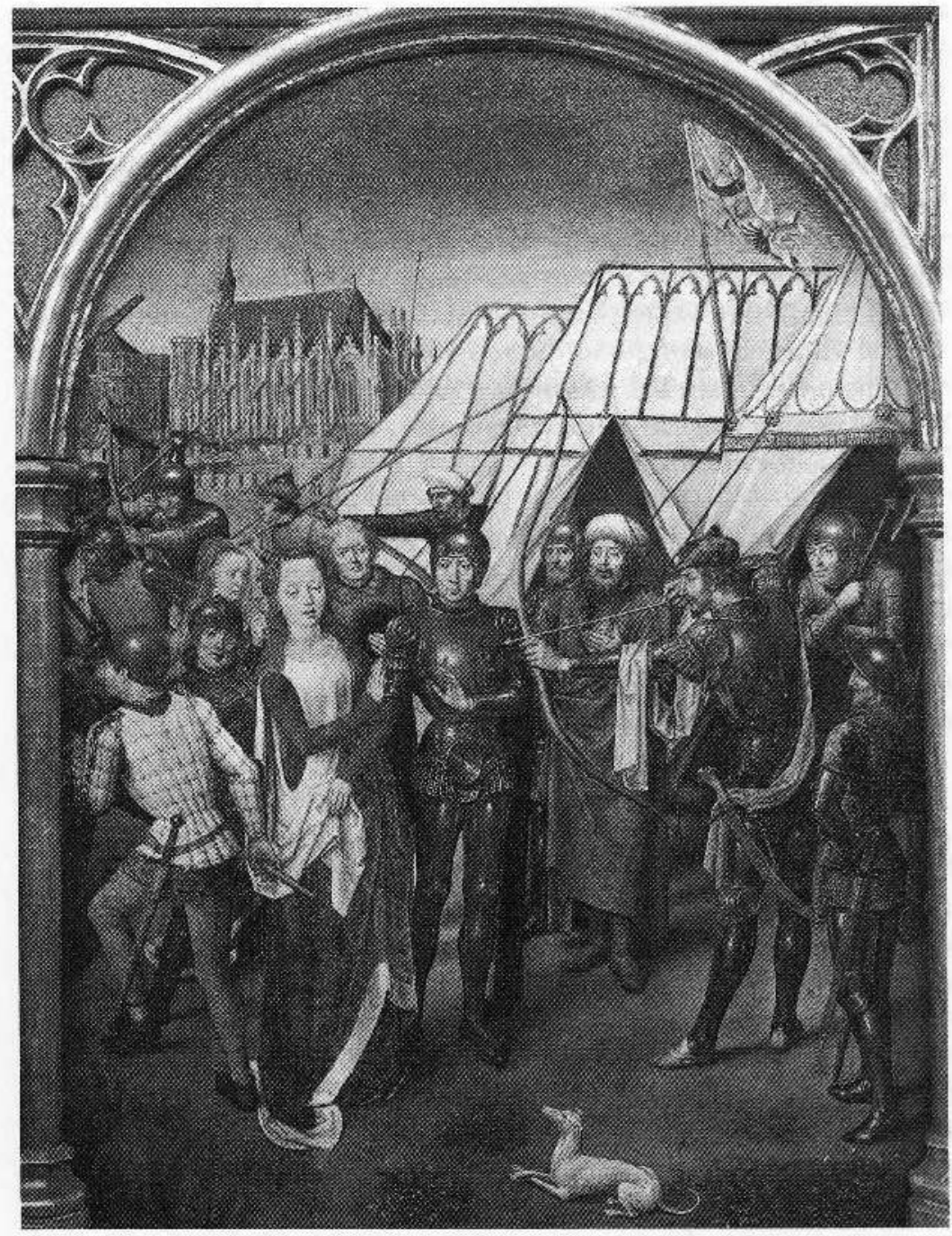

H. Memling, detail uit het Ursulaschrijn. Brugge, Memlingmuseum

Bruggelingen zijn, alhocwel onmiddellijk dient opgemerkt dat onze bevindingen de hypothese van het zelfportret in feite ondersteunen. ${ }^{10}$ Hierbij stelt zich dan onmiddellijk de vraag of er misschien nog andere zaken afgebeeld zijn die naar de eigen turbulente tijd

90 Lobelle-Cialuwe H.: Hans Memling: A Self-Portrait? In: Memling studies. Proceedings of the International Colloquium (Bruges, 10-12 November 1994), edited by Hélène Verougstraete, Roger Van Schoute, Maurits Smeyers with the collaboration of Anne Dubois, Leuven, 1997, p.43-52. 
verwijzen die de Bruggelingen, en dus ook Memling zelf, op het moment dat het schrijn geschilderd wordt, beleven?

Boven de tent van de Hunnenkoning waait een vaandel. Het vaandel is wat geplooid en er is ook een hoorn op afgebeeld, maar onmiskenbaar, weliswaar gecamoufleerd door een plooi in de vlag, is de vleugel van een gestileerde adelaar te zien. ${ }^{91}$ Het best gekende wapenschild op dat ogenblik met een gestileerde adelaar op, is dat van Maximiliaan van Oostenrijk. Men kan niet in ernst verwachten dat Memling het wapenschild van Maximiliaan voluit boven de tent van de Hunnenkoning had durven schilderen. Memling maakt hier volgens ons de parallel tussen de Hunnenkoning en de in de actualiteit, althans volgens de Brugse optiek, meinedige en moordende Maximiliaan van Oostenrijk.

In het verhaal van Ursula, zorgt ook de getulbande figuur op de voorgrond, voor interpretatieproblemen. D. Devos doet opmerken dat een dergelijke getulbande figuur in het overige werk van Memling bijna altijd een vorst uit het Oude Testament ofwel een Romeins keizer voorstelt. ${ }^{92}$ Wij menen hierin een bevestiging te zien van onze stelling, immers Maximiliaan is kort daarvoor op 9 april 1486 tot Rooms koning gekroond in Aken. De parallel tussen een afgebeelde Romeinse keizer en de Roomse koning, de toekomstige keizer, kan gemakkelijk gelegd worden. In de legende slacht de Hunnenkoning Ursula en haar gevolg af en in hetzelfde tafereel door symboliek ondergeschoven en stoelend op de Brugse realiteit van dat ogenblik, slacht Maximiliaan de Brugse bevolking af. Immers onder het gevolg van Ursula bevinden zich de eigentijdse, naar wordt aangenomen, Brugse burgers.

Onze stelling is dat de schilder Hans Memling in de harde confrontatie van 1488/90 partij kiest tegen Maximiliaan. Zonder Memling nu meteen te willen afschilderen als een politieke fanatiekeling, wat hij trouwens niet was, hiervoor "ontbreken" opnieuw de aanwijzingen, weten we toch, niettegenstaande de zeer beperkte kennis die we hebben over de sociale kring waarin de schilder verkeerde, dat hij contact met minstens nog één tegenstander van Maximiliaan onderhield, nl. Lodewijc de Valkenaere de bocraenverver, één van de voog-

91 Niemand heeft nog kumnen aantonen dat het wapenschild met hoorn en gestileerde adelaar aan een bestaande persoon of familie toebehoorde, zodat we mogen aannemen dat het wel degelijk om een fictief wapen gaat.

92 De Vos D.: Memling., p.300. 
den van zijn kinderen na het overlijden van zijn vrouw Tanne. Als bocraenverver maakte Lodewijc deel uit van het ambacht van de culcstickers. Welnu Lodewijc was lid van het ambachtsbestuur in 1477 en dan niet meer tot op het ogenblik dat de revolutionaire ambachtsbesturen worden aangesteld op 12 februari $1488 .{ }^{93}$ Wij hebben het nagetrokken, de leden die zetelen in de ambachtsbesturen aangesteld op 12 februari 1488 zijn tegenstanders van Maximiliaan. Een eerste argument dat die zienswijze ondersteunt komt voort uit de algemene omstandigheden waarin de wetsvernieuwing tot stand is gekomen. De nieuwe ambachtsbesturen worden niet langer door Maximiliaan aangesteld, maar wel in naam van de Drie Leden van Vlaanderen op gezag van de Franse koning. De bekendmaking gebeurt op de Markt waar de ambachten te wapen zijn gelopen..$^{94}$ Bij nader toezien zijn de bestuurders van februari 1488 bijna uitsluitend mensen die voorheen enkel in het bestuur zaten in die jaren dat de stad ook overhoop lag met Maximiliaan, ofwel kwamen ze reeds zeer lange tijd niet meer in aanmerking zoals Lodewijc of ze hadden voorheen nog nooit een mandaat uitgeoefend. ${ }^{95}$ We mogen dus rustig stellen dat één van de zeer weinige gekende vrienden van Memling eveneens een uitgesproken tegenstander van Maximiliaan was.

Conclusie. Onmiddellijk na zijn inschrijving als Brugs poorter werd Memling ook genoteerd als eigenaar van een "groot stenen huis". Ofschoon die laatste bewering een subjectief oordeel inhoudt, wijst dit er toch op dat Memling niet helemaal onbemiddeld naar Brugge gekomen is, tenzij natuurlijk het huis door zijn vrouw in de huwelijksgemeenschap zou gebracht zijn. Wanneer in 1486 vrouw Tanne overlijdt, toont de staat van goed dat Memling twee huizen naast elkaar bezit met nog een soort uitgang achter die huizen. Dit zou er kunnen op wijzen dat het Memling in de verlopen twintig jaar tot het overlijden van Tanne, financieel voor de wind gegaan is ofschoon iedere nadere informatie over hoe en wanneer het tweede huis verworven werd, ontbreekt. Vertrekkend vanuit het al dan niet aanwezig

$93 \mathrm{SAB}$, wetsvernieuwingen 1467-1501 f $175 \mathrm{r}$.

94 SAB, wetsvernieuwingen 1467-1501 f 172r. "Disendaghe den twaelfsten dach van spoorcle int jaer M IIIIc zevene ende tachtentich (= 1488 n.s.) zo was de wet vermaect van deser stede bijden commissarissen van de Drie Leden slands van Vlaenderen als daer toe gheauctoriseirt zijnde bijden conijnc van Vranckerijcke onsen souverainen heere ende zo dat bleec bij zekere commissie ter halle openbaerlic voor al tvolc ghelesen daer zij met hueren banieren ter maerct stonden.."

95 SAB, Wetsvernieuwingen 1467-1501, passim. 
zijn in gesloten bronnen, hebben we proberen te bewijzen dat na 1480 de financiële welvaart van Memling achteruit is gegaan. De stelling van betrekkelijke welvaart wordt ondersteund door het feit dat hij in mei 1480 door zijn tijdgenoten op basis van uiterlijke weelde, geselecteerd wordt om te participeren in de geforceerde lening. Wanneer de stad vanaf 1487 praktisch jaarlijks opnieuw geforceerde leningen oplegt, is Memling er nooit meer bij, wat wijst op een zekere financiële terugval, zowel absoluut als relatief. Ook in andere gesloten naamlijsten waar financiële transacties worden afgesloten, zoals de verkoop van stadsofficies en lijf- en losrenten door de stad verkocht, is de naam van Memling niet aanwezig. Door de vergelijking te maken met andere schilders zoals Fransoys vande Pitte en Jan Fabyaen kon ook aangetoond worden dat Memling zeker niet spectaculair hoger bezoldigd werd dan die twee. Trouwens het bedrag van $24 £$ gr. als schatting van het ganse roerend bezit na een beroepscarrière van ongeveer twintig jaar wijst in diezelfde richting. Bij zijn dood zien we niet meteen een in armoede gedompelde kunstenaar, maar een achteruitgang van welvaart kan met zekerheid afgelezen worden uit de staat van goed want zijn roerend bezit is in de laatste acht jaar met één derde verminderd.

Door zijn lidmaatschap van de broederschap van Onze-Lieve-Vrouwter-Sneeuw zou Memling sociale contacten hebben gehad in de hogere maatschappelijke kringen. Ook dit moet sterk gerelativeerd worden. Er zijn heelwat dergelijke broederschappen. De gilde van De Drogen Boom heeft minstens evenveel in aanzien staande leden als de broederschap van Onze-Lieve-Vrouw-ter-Sneeuw. Memling is ook niet de enige schilder die lid is. Zonder exhaustief onderzoek hebben we in de tekst toch de namen geciteerd van Jan Fabyaen, Petrus Christus en Gerard David. De bepaling in het testament van schout Pieter Lanchals waarbij hij van meerdere gilden lid is, wijst erop dat de lijst van de broederschappen met vooraanstaande leden, een open lijst is. De weinige sociale contacten van Memling waar we echt zeker van zijn, nl. de voogden van zijn kinderen, zijn ambachtslui, weliswaar beter gesitueerde ambachtslui, maar inderdaad ambachtslui.

Voorts kan ook gesteld worden dat de schilder Hans Memling door zijn eigen financiële achteruitgang en het gevoel van relatief tekort dat daar waarschijnlijk bij hoorde en ook gegrepen door de speciale sfeer die in de jaren 1488-1489 in de stad Brugge heerste, zijn politieke mening als tegenstander van Maximiliaan op dat ogenblik, heeft kenbaar gemaakt in het laatste tafereel van het Ursulaschrijn. 
Op die manier wordt ook een logische verklaring gegeven voor enkele interpretatieproblemen binnen dit tafereel. Is de oudere Brugse burger die op het zesde tafereel van het Ursulaschrijn geschilderd staat Memling zelf ?

Hardnekkig duikt de mening op dat Memling een soort bevoorrechte figuur binnen het Brugge van zijn tijd geweest zou zijn. Merkwaardig genoeg wordt daarvoor als argument naar voren geschoven dat hij nergens terug te vinden is in lijsten van het ambachtsbestuur of van stadsfuncties. Er dient vooreerst opgemerkt dat het aantal mensen dat niet in die lijsten terug te vinden is, zoals Memling, heelwat groter is dan het aantal dat er wel in voorkomt. Wij hopen dan ook met deze bijdrage het dieptezicht wat scherper gesteld te hebben op Hans Memling als Bruggeling onder de Bruggelingen. 